\title{
ANALISIS PENGARUH KINERJA KEUANGAN DAERAH TERHADAP TINGKAT KESEJAHTERAAN MASYARAKAT KABUPATEN MAJALENGKA - JAWA BARAT
}

\author{
Aceng Abdul Hamid)
}

1) dosen universitas pamulang, email : kangaceng88@gmail.com

\section{ARTICLES}

INFORMATION

ABSTRACT

\author{
JURNAL SEKURITAS \\ (Saham, Ekonomi, Keuangan \\ dan Investasi ) \\ Vol.1, No.4, Juni 2018 \\ Halaman : $38-51$ \\ C L LPPM \& Prodi Manajemen \\ UNIVERSITAS PAMULANG \\ ISSN (online) : 2581-2777 \\ ISSN (print) : :2581-2696
}

\section{Keyword :}

Financial performance, Income Per capita, level of education and life expectancy

JEL. classification :

C33, G20, G23, N65

\section{Contact Author :}

PRODI MANAJEMEN UNPAM

JL.Surya Kencana No.1 Pamulang

Tangerang Selatan - Banten

Telp. (021) 7412566, Fax (021) 7412491 Email :

jurnalfinance.unpam@gmail.com
Tujuan penelitian ini untuk mengetahui Pengaruh kinerja keuangan daerah terhadap Pendapatan Perkapita, Pengaruh kinerja keuangan daerah terhadap usia harapan hidup dan Pengaruh kinerja keuangan daerah terhadap Lama sekolah. Metode penelitian yang digunakan dalam penelitian ini adalah metode deskriptif, Pengujian asumsi klasik yang dilakukan terdiri atas uji normalitas, uji multikolinearitas, Uji Regresi Linier Berganda dan Uji Hipotesis. Hasil Penelitiannya adalah: (1) Terdapat pengaruh Kinerja keuangan daerah terhadap pendapatan perkapita, (2) Terdapat pengaruh Kinerja keuangan daerah terhadap Angka Usia Harapan Hidup, (3) Terdapat pengaruh Kinerja keuangan daerah terhadap Lama Sekolah.

The purpose of this study to determine the financial performance effect on income per capita, the financial performance effect on life expectancy and the financial performance effect on life expectancy the level of education. The research method used in this research is descriptive method. The classical assumption test consisted of normality test, multicollinearity test, Multiple Linear Regression Test and Hypothesis Test. The result of research are: (1) There is influence of the financial performance to income per capita, (2) There is influence of the financial performance to life expectancy, (3) There is influence of the financial performance to level of education. 


\section{A. Pendahuluan}

Negara Kesatuan Republik Indonesia telah menerapkan otonomi daerah selama 15 tahun. Sesuai dengan UU No.32 Tahun 2004) tentang pemerintahan daerah, Undang-undang Nomor 33 Tahun 2004 tentang perimbangan keuangan antara pemerintah pusat dan daerah. Penerapan perimbangan keuangan antara pemerintah pusat dan pemerintah daerah di Indonesia tercermin dalam penyelenggaraan pemerintahan dan pelayanan publik juga didasarkan atas azas desentralisasi, dekonsentrasi dan tugas pembantuan. Salah satu perwujudan pelaksanaan otonomi daerah adalah pelaksanaan desentralisasi, di mana Kepada Daerah diserahkan urusan, tugas dan wewenang untuk mengatur dan mengurus sendiri urusan pemerintahan dan kepentingan masyarakat setempat dengan tetap berpedoman pada peraturan perundang-undangan.

Penerapan otonomi daerah seutuhnya membawa konsekuensi logis berupa pelaksanaan penyelenggaraan pemerintahan dan pembangunan daerah berdasarkan manajemen keuangan yang sehat. Oleh karena itu, diperlukan sistem pengelolaan keuangan daerah yang baik dalam rangka mengelola dana APBD secara transparan, efisien, efektif dan akuntabel.

Salah satu alat ukur yang dapat digunakan untuk menganalisis kinerja pemerintah kabupaten dalam mengelola keuangan daerahnya adalah melakukan analisis rasio keuangan terhadap APBD yang telah ditetapkan dan dilaksanakan (Halim, 2007: 231).

Berkaitan dengan hal itu, analisis terhadap kinerja keuangan pemerintah kabupaten merupakan informasi yang penting terutama untuk membuat kebijakan dalam pengelolaan keuangan daerah dan menilai apakah pemerintah kabupaten berhasil mengelola keuangannya dengan baik, serta memberikan dampak yang positif terhadap kesejahteraan masyarakat. Analisis kinerja keuangan pada APBD dilakukan dengan cara membandingkan hasil yang dicapai dari setiap tahunnya, sehingga dapat diketahui bagaimana kecenderungan yang terjadi. Selain itu dapat pula dilakukan dengan cara menganalisis rasio-rasio keuangan. Rendahnya kapasitas dan kemampuan pengelolaan keuangan daerah akan sering menimbulkan siklus efek negatif, yaitu rendahnya tingkat pelayanan bagi masyarakat dan tidak mampu meningkatkan kesejahteraan masyarakat. Berikut Data indeks pembangunan manusia dari Badan Pusat Statistik :

Tabel 1.1

Indeks Pembangunan Manusia (IPM)

Provinsi Jawa Barat Tahun 2013

\begin{tabular}{|c|l|c|}
\hline NO & \multicolumn{1}{|c|}{ Kabupaten/ Kota } & IPM \\
\hline 1 & KOTA DEPOK & 80.1 \\
\hline 2 & KOTA BEKASI & 77.7 \\
\hline 3 & KOTA BANDUNG & 77.3 \\
\hline 4 & KOTA CIMAHI & 76.9 \\
\hline 5 & KOTA BOGOR & 76.8 \\
\hline 6 & KOTA CIREBON & 76.7 \\
\hline 7 & KOTA SUKABUMI & 76.2 \\
\hline 8 & KOTA TASIKMALAYA & 75.7 \\
\hline 9 & BANDUNG & 75.1 \\
\hline
\end{tabular}

\begin{tabular}{|c|l|r|}
\hline NO & \multicolumn{1}{|c|}{ Kabupaten/ Kota } & \multicolumn{1}{c|}{ IPM } \\
\hline 15 & KOTA BANJAR & 72.84 \\
\hline 16 & PURWAKARTA & 72.75 \\
\hline 17 & CIAMIS & 72.68 \\
\hline 18 & KUNINGAN & 72.47 \\
\hline 19 & GARUT & 72.43 \\
\hline 20 & SUBANG & 72.1 \\
\hline 21 & SUKABUMI & 71.96 \\
\hline $\mathbf{2 2}$ & MAJALENGKA & $\mathbf{7 1 . 9}$ \\
\hline 23 & KARAWANG & 71.56 \\
\hline
\end{tabular}




\begin{tabular}{|l|l|l|}
10 & BEKASI & 74.8 \\
\hline 11 & BANDUNG BARAT & 74.6 \\
\hline 12 & BOGOR & 73.9 \\
\hline 13 & SUMEDANG & 73.6 \\
\hline 14 & TASIKMALAYA & 73.3 \\
\hline \multicolumn{2}{|c|}{ Sumber : www.bps.go.id } \\
\end{tabular}

\begin{tabular}{|l|l|l|}
24 & PANGANDARAN & 70.74 \\
\hline 25 & CIANJUR & 70.38 \\
\hline 26 & CIREBON & 70.25 \\
\hline 27 & INDRAMAYU & 69.52 \\
\hline
\end{tabular}

Berdasarkan table 1.1 di atas, dapat dijelaskan bahwa Kota Depok menempati urutan pertama sebagai kota/ kabupaten dengan indeks pembangunan manusia tertinggi yang disusul dengan Kota Bekasi dan Kota bandung sebagai urutan ketiga. Sedangkan Majalengka menempati urutan ke-22 yang diikuti oleh Karawang, Pangandaran, Cianjur, Cirebon dan Indramayu pada urutan terakhir. Kabupaten Majalengka masih berada dibawah rata - rata IPM Jawa Barat yang berada pada angka 73,58.

Dalam penelitian ini, penulis memilih Kabupaten Majalengka sebagai obyek penelitian terhadap kinerja keuangan pemerintah kabupaten dan tingkat kesejahteraan masyarakat selain sebagai 'putera daerah' penulis juga ingin memberikan kontribusi terhadap perkembangan dan kemajuan daerah Majalengka dengan mengkaji kinerja pemerintah kabupaten dan kesejahteraan masyarakat sehingga dapat memberikan masukan dan saran-saran demi perbaikan kinerja pemerintah kabupaten dan kesejahteraan masyarakat di Kabupaten Majalengka ke arah yang lebih baik.

Dari data pembanding antar seluruh kabupaten/ kota di Jawa Barat. Diketahui bahwa kabupaten Majalengka merupakan kabupaten dengan indeks IPM terendah dibanding kabupaten - kabupaten lainnya dengan peringkat 6 terendah.

Untuk melihat realisasi pendapatan daerah dengan tingkat kesejahteraan masyarakat diantaranya dapat dilihat berdasarkan pendapatan perkapita dari penduduk kabupaten Majalengka yang akan disajikan pada tabel 1.2 berikut ini:

Tabel 1.2

Pendapatan Asli daerah vs Pendapatan Perkapita Kabupaten Majalengka

\begin{tabular}{|c|c|c|}
\hline Tahun & PAD & $\begin{array}{c}\text { Pendapatan } \\
\text { Perkapita }\end{array}$ \\
\hline 2004 & $25.303 .590 .000,00$ & $2.851 .121,63$ \\
\hline 2005 & $32.270 .220 .000,00$ & $2.916 .382,85$ \\
\hline 2006 & $50.043 .010 .000,00$ & $3.175 .878,59$ \\
\hline 2007 & $46.020 .646 .259,00$ & $3.312 .857,44$ \\
\hline 2008 & $47.721 .941 .970,00$ & $3.448 .048,44$ \\
\hline 2009 & $68.121 .599 .611,00$ & $3.598 .486,33$ \\
\hline 2010 & $76.398 .018 .123,00$ & $3.755 .455,75$ \\
\hline 2011 & $86.579 .536 .411,00$ & $3.903 .266,00$ \\
\hline 2012 & $103.740 .974 .491,00$ & $4.082 .914,00$ \\
\hline 2013 & $142.505 .677 .495,00$ & $4.172 .977,00$ \\
\hline Rata - rata & $\mathbf{6 7 . 8 7 0 . 5 2 1 . 4 3 6 , 0 0}$ & $\mathbf{3 . 5 2 1 . 7 3 8 , 8 0}$ \\
\hline
\end{tabular}

Pada tabel 1.2 menunjukkan bahwa pendapatan perkapita penduduk kabupaten Majalengka semakin meningkat setiap tahunnya. Walaupun pendapatan daerah sempat mengalami penurunan namun trend perngeluran perkapita penduduk terus meningkat. Semakin meningkatnya PAD seharusnya kabupaten Majalengka 
dapat dengan cepat untuk mensejahterakan masyarakatnya dengan menyesuaikan anggaran yang telah ada. Apalagi saat ini di Kabupaten Majalengka sedang dilaksanakan mega proyek Bandara International Kertajati sehingga pembangunan infrastruktur menjadi prioritas pemerintah daerah provinsi Jawa Barat. Sehingga dapat memboosting pendapatan daerah dan masyarakat.

Pemerintah kabupaten melalui rencana kerja yang dirumuskan dalam "Panca Program" pemerintah kabupaten, salah satu di antaranya adalah fokus pada upaya pengentasan kemiskinan dan meningkatkan kesejahteraan masyarakat di seluruh aspek kehidupan serta pembanguan infrastruktur untuk mewujudkan Kabupaten Majalengka sebagai pusat perkembangan ekonomi Jawa Barat.

\section{B. Perumusan Masalah}

1. Apakah kinerja keuangan daerah Kabupaten Majalengka dalam bentuk Kemandirian Daerah, Efektifitas, Efisiensi dan Keserasian belanja keuangan pemerintah dapat berpengaruh terhadap tingkat Kesejahteraan Masyarakat berupa Pendapatan Perkapita?

2. Apakah kinerja keuangan daerah Kabupaten Majalengka dalam bentuk Kemandirian Daerah, Efektifitas, Efisiensi dan Keserasian belanja keuangan pemerintah dapat berpengaruh terhadap tingkat Kesejahteraan Masyarakat berupa Usia Harapan Hidup?

3. Apakah kinerja keuangan daerah Kabupaten Majalengka dalam bentuk Kemandirian Daerah, Efektifitas, Efisiensi dan Keserasian belanja keuangan pemerintah dapat berpengaruh terhadap tingkat Kesejahteraan Masyarakat berupa Lama Sekolah?

\section{Tujuan Penelitian}

1. Mengetahui pengaruh kinerja keuangan daerah Kabupaten Majalengka dalam bentuk Kemandirian Daerah, Efektifitas, Efisiensi dan Keserasian belanja keuangan pemerintah terhadap tingkat Kesejahteraan Masyarakat berupa Pendapatan Perkapita.

2. Mengetahui pengaruh kinerja keuangan daerah Kabupaten Majalengka dalam bentuk Kemandirian Daerah, Efektifitas, Efisiensi dan Keserasian belanja keuangan pemerintah terhadap tingkat Kesejahteraan Masyarakat berupa Usia Harapan Hidup.

3. Mengetahui pengaruh kinerja keuangan daerah Kabupaten Majalengka dalam bentuk Kemandirian Daerah, Efektifitas, Efisiensi dan Keserasian belanja keuangan pemerintah terhadap tingkat Kesejahteraan Masyarakat berupa Lama Sekolah.

\section{Landasan Teori}

\section{Keuangan Daerah}

Faktor keuangan merupakan hal yang penting dalam mengukur tingkat kemampuan daerah dalam melaksanakan otonominya. Keadaan keuangan daerahlah yang menentukan bentuk dan ragam yang akan dilakukan oleh pemerintah daerah. Halim (2007: 230), mengungkapkan bahwa kemampuan pemerintah daerah dalam mengelola keuangan daerah dituangkan dalam 
Anggaran Pendapatan dan Belanja Daerah (APBD) yang langsung maupun tidak langsung mencerminkan kemampuan pemerintah daerah dalam membiayai pelaksanaan tugas-tugas pemerintahan, pembangunan dan pelayanan sosial masyarakat.

Selanjutnya untuk mengukur kemampuan keuangan pemerintah daerah adalah dengan melakukan analisis rasio keuangan terhadap APBD yang telah ditetapkan dan dilaksanakannya.

\section{Laporan Keuangan Daerah}

Sebagai upaya konkrit untuk mewujudkan transparansi dan akuntabilitas pengelolaan keuangan negara/daerah adalah penyampaian laporan pertanggungjawaban keuangan pemerintah yang memenuhi prinsip tepat waktu dan dapat diandalkan (reliable) serta disusun dengan mengikuti standar akuntansi pemerintahan (SAP) yang telah diterima secara umum. Hal ini diatur dalam UU No. 1 Tahun 2004 tentang Perbendaharaan Negara, PP No. 58/2005, PP No.38/ 2007, Permendagri No. 65/2007 dan Permendagri No. 13/2006. Semua peraturan ini mensyaratkan bentuk dan isi laporan pertanggungjawaban pelaksanaan APBN/APBD disusun dan disajikan sesuai dengan SAP yang ditetapkan dengan peraturan pemerintah.

\section{Kinerja Keuangan Daerah}

Kinerja keuangan adalah suatu ukuran kinerja yang menggunakan indikator keuangan. Analisis kinerja keuangan pada dasarnya dilakuan untuk menilai kinerja di masa lalu dengan melakukan berbagai analisis sehingga diperoleh posisi keuangan yang mewakili realitas entitas dan potensi-potensi kinerja yang akan berlanjut.

Keputusan strategis disusun melalui kebijakan untuk mencapai sasaran dan target yang diinginkan. Pencapaian sasaran dan target membutuhkan informasi tentang aktual kinerja yang diharapkan dengan membandingkan kebijakan yang ditetapkan (setting objectives). Informasi yang diharapkan harus tersusun, dan merupakan desain pengukuran kinerja dan indikator yang terurai dan jelas.

\section{Analisis Rasio Keuangan Daerah}

Beberapa rasio keuangan yang dapat digunakan untuk mengukur akuntabilitas pemerintah daerah (Halim, 2007: 233) yaitu rasio kemandirian, rasio efektivitas, rasio efisiensi keuangan daerah dan rasio keserasian belanja.

a. Rasio kemandirian keuangan daerah

Rasio kemandirian keuangan daerah menunjukkan kemampuan pemerintah daerah dalam membiayai sendiri kegiatan pemerintahan, pembangunan dan pelayanan kepada masyarakat. Rasio kemandirian dihitung dengan membagi total PAD dengan total belanja daerah dalam satuan persen (Suyana Utama, 2008:33).

Secara sederhana rasio kemandirian dapat diformulasikan sebagai berikut (Mahsun dalam Suyana Utama, 2008: 33) :

$$
\text { Rasio Kemandirian }=\frac{\text { Pendapatan Asli Daerah }}{\text { Total Belanja Daerah }} \times 100 \%
$$

Pola hubungan pemerintah pusat dan daerah serta tingkat kemandirian dan kemampuan keuangan daerah dapat disajikan dalam matriks seperti tampak pada Tabel 2-1 berikut ini (Mahsun, 2006: 187) 
Tabel 2.1

Pola Hubungan, Tingkat Kemandirian, dan Kemampuan Keuangan

Daerah

\begin{tabular}{|c|c|c|}
\hline $\begin{array}{c}\text { Kemampuan } \\
\text { Keuangan }\end{array}$ & $\begin{array}{c}\text { Rasio Kemandirian } \\
(\%)\end{array}$ & $\begin{array}{c}\text { Pola } \\
\text { Hubungan }\end{array}$ \\
\hline Rendah Sekali & $0-25$ & Instruktif \\
\hline Rendah & $>25-50$ & Konsultatif \\
\hline Sedang & $>50-75$ & Partisipatif \\
\hline Tinggi & $>75-100$ & Delegatif \\
\hline
\end{tabular}

Sumber : Mahsun Moh, 2006 (187)

b. Rasio efektivitas keuangan daerah

Pengertian efektivitas berhubungan dengan derajat keberhasilan suatu operasi pada sektor publik sehingga suatu kegiatan dikatakan efektif jika kegiatan tersebut mempunyai pengaruh besar terhadap kemampuan menyediakan pelayanan masyarakat yang merupakan sasaran yang telah ditetapkan sebelumnya. Rasio efektivitas merupakan tingkat pencapaian pelaksanaan suatu kegiatan atau prestasi yang dicapai oleh pemerintah daerah yang diukur dengan membandingkan realisasi pendapatan dengan anggaran pendapatan, dalam satuan persen (Suyana Utama, 2008:27).

Rasio efektivitas diukur dengan : (Suyana Utama, 2008: 33):

\section{Rasio Efektivitas $=\frac{\text { Realisasi Pendapat }}{\text { Anggaran Pendapatan }} \times 100 \%$}

Nilai efektivitas diperoleh dari perbandingan sebagaimana tersebut diatas, diukur dengan kriteria penilaian kinerja keuangan (Mahsun, 2006:187).

Tabel 2.2

Efektivitas Keuangan Daerah

\begin{tabular}{|c|c|}
\hline $\begin{array}{c}\text { Efektivitas Keuangan Daerah Otonom } \\
\text { dan } \\
\text { Kemampuan Keuangan }\end{array}$ & $\begin{array}{c}\text { Rasio } \\
\text { Efektivitas }\end{array}$ \\
\hline Sangat Efektif & $>100$ \\
\hline Efektif & $>90-100$ \\
\hline Cukup Efektif & $>80-90$ \\
\hline Kurang Efektif & $>60-80$ \\
\hline Tidak Efektif & $<=60$ \\
\hline
\end{tabular}

Sumber : Mahsun Moh, 2006 (187)

c. Rasio efisiensi keuangan daerah

Rasio efisiensi merupakan tingkat pencapaian pelaksanaan suatu kegiatan atau prestasi yang dicapai oleh pemerintah daerah yang diukur dengan membandingkan realisasi belanja dengan anggaran belanja yang telah ditetapkan, dalam satuan persen (Suyana Utama, 2008:30).

Rasio efisiensi diukur dengan (Suyana Utama, 2008: 33) : 


\section{Rasio Efisiensi $=\frac{\text { Realisasi Belanja Daerah }}{\text { Anggaran Belanja Daerah }} \times 100 \%$}

Dengan mengetahui hasil perbandingan antara realisasi belanja dananggaran belanja daerah dengan menggunakan ukuran efisiensi tersebut, maka penilaian kinerja keuangan dapat ditentukan (Mahsun, 2006: 187).

Tabel 2.3

Efisiensi Keuangan Daerah

\begin{tabular}{|c|c|}
\hline $\begin{array}{c}\text { Efisiensi Keuangan Daerah Otonom dan } \\
\text { Kemampuan Keuangan }\end{array}$ & $\begin{array}{c}\text { Rasio } \\
\text { Efisiensi }\end{array}$ \\
\hline Sangat Efisien & $<=60$ \\
\hline Efisien & $>60-80$ \\
\hline Cukup Efisien & $>80-90$ \\
\hline Kurang Efisien & $>=100$ \\
\hline Tidak Efisien & \\
\hline
\end{tabular}

Sumber : Mahsun Moh, 2006

d. Rasio Keserasian Belanja

Rasio keserasian menggambarkan bagaimana pemerintah daerah memprioritaskan alokasi dananya pada belanja aparatur dan belanja pelayanan publik secara optimal. Dalam penelitian ini digunakan proprosi belanja publik karena belanja publik secara langsung dimaksudkan untuk dapat meningkatkan kesejahteraan hidup masyarakat. Rasio keserasian diukur dengan membandingkan realisasi total belanja publik dengan total belanja daerah dalam satuan persen (Suyana Utama, 2008:36).

Secara sedarhana rasio keserasian belanja dapat diformulasikan sebagai berikut (Suyana Utama, 2008) :

Rasio Keserasian $=\frac{\text { Belanja Pelayanan Publik }}{\text { Total Belanja Daerah }} \times 100 \%$

Dengan mengetahui hasil perbandingan antara realisasi belanja dan anggaran belanja daerah dengan menggunakan ukuran efisiensi tersebut, maka penilaian kinerja keuangan dapat ditentukan sebagai berikut (Mahsun, 2006) :

Tabel 2.4

Keserasian Belanja Keuangan Daerah

Keserasian Belanja Keuangan Daerah otonom

Rasio Keserasian Belanja (\%)

\begin{tabular}{|c|c|}
\hline Tidak Serasi & $0-20$ \\
\hline Kurang Serasi & $>20-40$ \\
\hline Cukup Serasi & $>40-60$ \\
\hline Serasi & $>60-80$ \\
\hline Sangat Serasi & $>80-100$ \\
\hline
\end{tabular}

Sumber : Mahsun Moh, 2006 


\section{Kesejahteraan Masyarakat}

Menurut United Nations Development Programme (UNDP), pembangunan manusia merupakan suatu model pembangunan yang ditujukan untuk memperluas pilihan bagi penduduk yang dapat ditumbuhkan melalui upaya pemberdayaan penduduk. Hal ini dapat dicapai melalui program pembangunan yang menitik-beratkan pada peningkatan kemampuan dasar manusia yaitu meningkatnya derajat kesehatan, berupa umur panjang dan hidup sehat, mempunyai pengetahuan dan keterampilan yang memadai agar dapat digunakan untuk mempertinggi partisipasi dalam kegiatan ekonomi produktif serta mendapat penghasilan yang mencukupi dengan daya beli yang layak.

Pendapatan perkapita adalah PDRB berdasarkan harga yang berlaku di masyarakat dibagi dengan total penduduk pada pertengahan tahun, dalam ribuan rupiah. PDRB adalah total nilai tambah yang dihasilkan oleh sektorsektor perekonomian dalam kurun waktu satu tahun. Tingkat pendidikan masyarakat diukur dari jumlah penduduk yang menamatkan bangku pendidikan formal terhadap total penduduk di suatu wilayah tertentu, dalam satuan persen. Usia harapan hidup adalah rata-rata umur masyarakat yang dicapai pada suatu wilayah tertentu, dalam satuan tahun.

\section{E. Metodologi}

Penelitian ini digolongkan kedalam penelitian kausalitas, penelitian ini melakukan percobaan dalam memprediksi pengaruh dari satu variabel dengan variabel lainnya (Cooper and Schindler, 2008; 144), kemudian uraian yang mengungkapkan besar atau kecilnya suatu pengaruh atau hubungan antar variabel yang dinyatakan dalam angka-angka. Penelitian ini menguji pengaruh Tingkat Kinerja Keuangan Daerah Terhadap Kesejahteraan Masyarakat. Populasi terdiri atas: obyek/subyek yang mempunyai kualitas dan karakterisitik tertentu yang ditetapkan oleh peneliti untuk dipelajari dan kemudian ditarik kesimpulannya (Sugiyono, 2012:119). Objek dari penelitian ini adalah Laporan keuangan Daerah Kabupaten Majalengka.

Metode penelitian yang digunakan dalam penelitian ini adalah metode deskriptif memberikan gambaran atau deskripsi suatu data yang dilihat dari nilai rata-rata (mean), standar variasi, varian, maksimum, minimum, sum, range, kurtosis dan skewness (kemencengan distribusi). Pengujian asumsi klasik yang dilakukan terdiri atas uji normalitas, uji autokorelasi, uji multikolinearitas, dan uji heteroskedastisitas. Uji Regresi Linier Berganda, Uji Koefisien Korelasi, Uji Koefisien Determinasi, dan Uji Hipotesis.

\section{F. Hasil dan Pembahasan}

Metode analisis data yang digunakan dalam penelitian ini adalah metode statistik dengan menggunakan program SPSS versi 22.0.

\section{Uji Asumsi Klasik}

a. Uji Normalitas

Menurut Imam Ghozali (2013:160) Uji normalitas bertujuan untuk menguji apakah model regresi, variabel pengganggu atau residual memiliki distribusi normal. 
Uji normalitas dengan analisis grafik pada penelitian ini menggunakan normal probability plot, yaitu deteksi dengan melihat penyebaran data (titik) pada sumbu diagonal dari grafik. Berikut ini adalah hasil dari pengujian uji normalitas dengan menggunakan grafik normal probability plot.

\section{Gambar 4.4 \\ Normal Probability Plot}

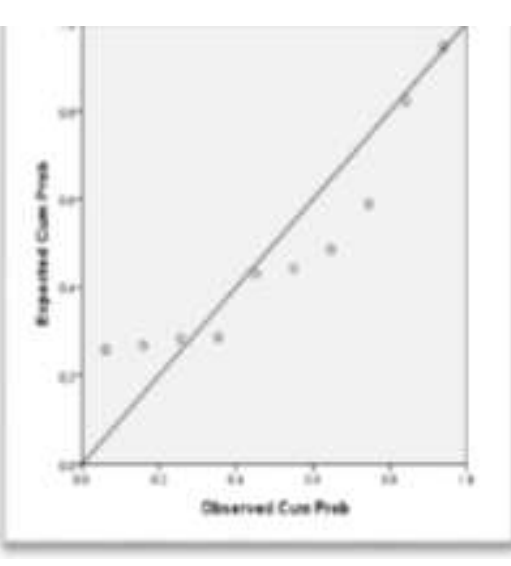

Pendapatan Perkapita Lama Sekolah
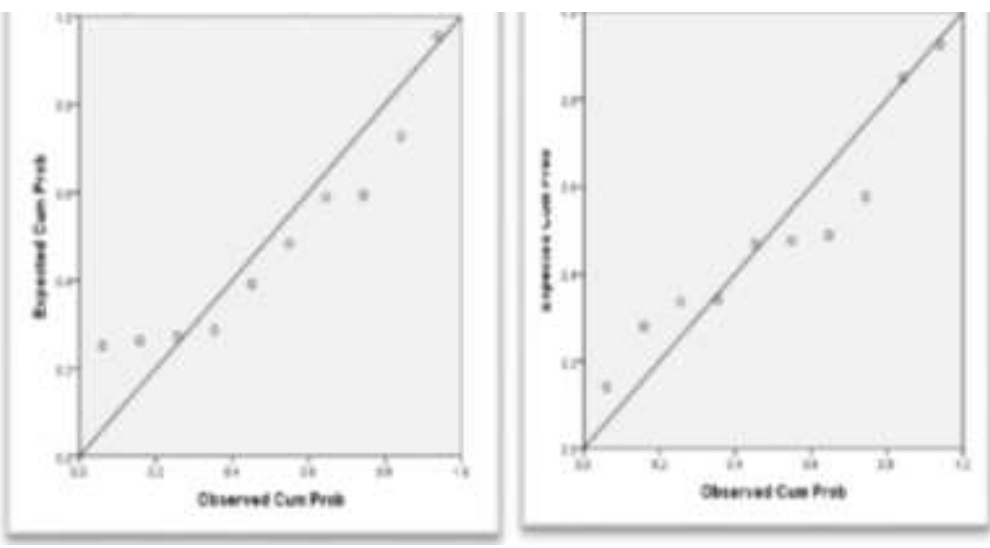

Harapan Hidup

Sumber : Data diolah menggunakan SPSS 22, 2015.

Dari hasil normal probability plot diatas dapat dilihat bahwa Sebaran titik-titik dari gambar Normal P-P Plot di atas relatif mendekati garis lurus. Hal seperti ini dapat disimpulkan bahwa data terdistribusi normal atau memenuhi asumsi klasik normalitas.

\section{b. Uji Multikolonieritas}

Menurut Imam Ghozali (2013:105) uji multikolonieritas bertujuan untuk menguji apakah model regresi ditemukan adanya korelasi antar variabel bebas (independen). Model regresi yang baik adalah tidak terjadi korelasi di antara variabel indipenden. Multikolonieritas dapat juga dilihat dari nilai tolerance dan lawannya variance inflation factor (VIF). Nilai cutoff yang umum dipakai untuk menunjukkan adanya multikolonieritas adalah nilai Tolerance $\leq 0,10$ atau sama dengan nilai VIF $\geq 10$. Berikut ini adalah hasil uji multikolonieritas:

Hasil Uji Multikolonearitas

Variabel Independent

\begin{tabular}{|l|r|r|l|}
\hline \multicolumn{1}{|c|}{ Variabel } & Tolerance & \multicolumn{1}{c|}{ VIF } & \multicolumn{1}{c|}{ Keputusan } \\
\hline $\begin{array}{l}\text { Kemandirian } \\
\text { Daerah }\end{array}$ & 0,597 & 1,675 & $\begin{array}{l}\text { Bebas } \\
\text { multikolonieritas }\end{array}$ \\
\hline Efektivitas & 0,590 & 1,693 & $\begin{array}{l}\text { Bebas } \\
\text { multikolonieritas }\end{array}$ \\
\hline Efisiensi & 0,506 & 1,977 & $\begin{array}{l}\text { Bebas } \\
\text { multikolonieritas }\end{array}$ \\
\hline Keserasian Belanja & 0,708 & 1,413 & $\begin{array}{l}\text { Bebas } \\
\text { multikolonieritas }\end{array}$ \\
\hline
\end{tabular}

Sumber : data yang telah diolah (SPSS 22.0) 
Dari hasil uji multikolonieritas di atas, menunjukkan bahwa dapat dilihat bahwa Rasio Kemandirian Daerah, Rasio Efektivitas, Rasio Efisiensi dan Keserasian Belanja menunjukkan nilai tolerance $>0,10$ dan nilai VIF $<10$. Oleh karena itu dapat disimpulkan bahwa variabel independen yang digunakan dalam model regresi penelitian ini adalah terbebas dari multikolonieritas atau dengan kata lain dapat dipercaya dan objektif.

\section{Hasil Pengujian Hipotesis}

Berdasarkan hasil uji statistik $\mathrm{F}$ di bawah, output regresi menunjukkan nilai signifikansi 0.000 atau dibawah tingkat signifikansi 0,05 , sehingga dapat disimpulkan bahwa selama periode yang digunakan, variabel Kemandirian Daerah, Efisiensi, Efektivitas dan Keserasian belanja secara bersama-sama dapat menjelaskan pengaruh terhadap variabel dependen (Pendapatan Perkapita, Angka Usia Harapan Hidup dan Lama Sekolah).

Ringkasan Hasil Uji Hipotesis

\begin{tabular}{|l|c|c|c|c|c|}
\hline \multicolumn{1}{|c|}{ Variabel } & F & Sig & $\begin{array}{c}\mathbf{R} \\
\text { Square }\end{array}$ & $\begin{array}{c}\text { Adjusted } \\
\mathbf{R} \\
\text { Square }\end{array}$ & Std Error \\
\hline Pendapatan Perkapita & 6.804 & 0.030 & 0.845 & 0.721 & $244.766,74$ \\
\hline $\begin{array}{l}\text { Angka Usia Harapan } \\
\text { Hidup }\end{array}$ & 8.584 & 0.018 & 0.873 & 0.771 & 0.42922 \\
\hline Lama Sekolah & 8.195 & 0.020 & 0.868 & 0.762 & 0.20787 \\
\hline
\end{tabular}

\section{Pendapatan Perkapita}

Dari tabel diatas dapat dilihat nilai $F$ hitung yaitu 6.804 , sedangkan nilai $F$ tabel dapat diperoleh dengan menggunakan tabel $F$ dengan derajat bebas (df) Residual (sisa) yaitu 5 sebagai df penyebut dan df Regression (perlakuan) yaitu 4 sebagai df pembilang dengan tarap siginifikan 0,05 , sehingga diperoleh nilai $F$ tabel yaitu 5,19 . Karena $F$ hitung $(6,804)>F$ tabel $(5,19)$ maka Ho ditolak.

Berdasarkan hasil pengujian koefisien determinasi dalam tabel, dapat dilihat bahwa besarnya Adjusted R2 adalah 0,721. Hal ini berarti $72,1 \%$ variasi pendapatan perkapita dapat dijelaskan oleh 4 variabel independen yaitu Kemandirian Daerah, Efektivitas Keuangan Daerah, Efisiensi Daerah, dan Keserasian Belanja. Sedangkan sisanya $(100 \%-72,1 \%=27,9 \%)$ dijelaskan oleh sebab-sebab lain di luar model.

Pada tabel diatas angka $\mathrm{R}$ Square adalah 0,845 yaitu hasil kuadrat dari koefisien korelasi $(0,919 \times 0,919=0,845)$. Standar Error of the Estimate adalah 244.766,73908 sedangkan pada analisis deskriptif statitik bahwa standar deviasi pendapatan perkapita adalah 463.077,84204 yang jauh lebih besar dari standar error, oleh karena lebih kecil daripada standar deviasi pendapatan perkapita maka model regresi sangat bagus dalam bertindak sebagai predictor pendapatan perkapita.

\section{Angka Usian Harapan Hidup}

Dari tabel diatas dapat dilihat nilai $F$ hitung yaitu 8,584 , sedangkan nilai $F$ tabel dapat diperoleh dengan menggunakan tabel $F$ dengan derajat bebas (df) Residual (sisa) yaitu 5 sebagai df penyebut dan df Regression (perlakuan) yaitu 4 sebagai df pembilang dengan tarap siginifikan 0,05 , sehingga diperoleh nilai $F$ tabel yaitu 5,19 . Karena $F$ hitung $(8,584)>F$ tabel $(5,19)$ maka Ho ditolak. 
Berdasarkan hasil pengujian koefisien determinasi dalam tabel diatas, dapat dilihat bahwa besarnya Adjusted $R$ Square adalah 0,771 . Hal ini berarti $77,1 \%$ variasi usia harapan hidup dapat dijelaskan oleh 4 variabel independen yaitu Kemandirian Daerah, Efektivitas Keuangan Daerah, Efisiensi Daerah, dan Keserasian Belanja. Sedangkan sisanya $(100 \%-77,1 \%=22,9 \%)$ dijelaskan oleh sebab-sebab lain di luar model.

Pada tabel diatas angka $\mathrm{R}$ Square adalah 0,873 yaitu hasil kuadrat dari koefisien korelasi $(0,934 \times 0,934=0,873)$. Standar Error of the Estimate adalah 0,42922 sedangkan pada analisis deskriptif statitik bahwa standar deviasi usia harapan hidup adalah 0,89735 yang jauh lebih besar dari standar error, oleh karena lebih kecil daripada standar deviasi usia harapn hidup maka model regresi sangat bagus dalam bertindak sebagai predictor usia harapan hidup.

\section{Lama Sekolah}

Dari tabel diatas dapat dilihat nilai $F$ hitung yaitu 8,195 , sedangkan nilai $F$ tabel dapat diperoleh dengan menggunakan tabel $F$ dengan derajat bebas (df) Residual (sisa) yaitu 5 sebagai df penyebut dan df Regression (perlakuan) yaitu 4 sebagai df pembilang dengan tarap siginifikan 0,05 , sehingga diperoleh nilai $F$ tabel yaitu 5,19 . Karena $F$ hitung $(8,195)>F$ tabel $(5,19)$ maka Ho ditolak.

Berdasarkan hasil pengujian koefisien determinasi dalam tabel, dapat dilihat bahwa besarnya Adjusted $R$ Square adalah 0,762 . Hal ini berarti $76,2 \%$ variasi lama sekolah dapat dijelaskan oleh 4 variabel independen yaitu Kemandirian Daerah, Efektivitas Keuangan Daerah, Efisiensi Daerah, dan Keserasian Belanja. Sedangkan sisanya $(100 \%-76,2 \%=23,8 \%)$ dijelaskan oleh sebab-sebab lain di luar model.

Pada tabel diatas angka $\mathrm{R}$ Square adalah 0,868 yaitu hasil kuadrat dari koefisien korelasi $(0,931 \times 0,931=0,868)$. Standar Error of the Estimate adalah 0.20787 sedangkan pada analisis deskriptif statitik bahwa standar deviasi lama sekolah adalah 0.42590 yang jauh lebih besar dari standar error, oleh karena lebih kecil daripada standar deviasi lama sekolah maka model regresi sangat bagus dalam bertindak sebagai predictor lama sekolah.

\section{G. Kesimpulan}

1. Kinerja keuangan daerah berupa kemandirian daerah, efisiensi, efektifitas dan keserasian belanja keuangan pemerintah daerah secara bersama - sama berpengaruh positif signifikan terhadap tingkat kesejahteraan masyarakat Kabupaten Majalengka berupa Pendapatan Perkapita dengan nilai koefisien determinasi sebesar ( $R$ Square) $84,5 \%$.

2. Kinerja keuangan daerah berupa kemandirian daerah, efisiensi, efektifitas dan keserasian belanja keuangan pemerintah daerah secara bersama - sama berpengaruh positif signifikan terhadap tingkat kesejahteraan masyarakat Kabupaten Majalengka berupa Angka Usia Harapan Hidup dengan nilai koefisien determinasi sebesar ( $R$ Square) $87,3 \%$.

3. Kinerja keuangan daerah berupa kemandirian daerah, efisiensi, efektifitas dan keserasian belanja keuangan pemerintah daerah secara bersama - sama berpengaruh positif signifikan terhadap tingkat kesejahteraan masyarakat Kabupaten Majalengka berupa Lama Sekolah dengan nilai koefisien determinasi sebesar ( $R$ Square) $86,8 \%$. 


\section{H. Saran}

1. Pemerintah Kabupaten Majalengka diharapkan untuk lebih memperhatikan, mengakomodir, memanfaatkan dan memberdayakan sumber-sumber PAD yang dimiliki daerah ketika menyusun anggaran pendapatan seperti pemanfaatan sumber-sumber retribusi, pengembangan potensi-potensi alam di sektor pariwisata dan pertanian sehingga mampu mendorong pencapaian realisasi pendapatan asli daerah yang optimal dan meningkatkan PAD guna mengurangi ketergantungan daerah terhadap bantuan pemerintah pusat dan provinsi.

2. Pemerintah Kabupaten Majalengka hendaknya tidak selalu mengandalkan sumber-sumber pendapatan non PAD, seperti yang selama ini terjadi untuk mengurangi tingkat ketergantungan terhadap pihak luar. Oleh karena itu, upaya menciptakan sumber-sumber baru pendapatan asli daerah perlu mendapat perhatian dan keseriusan di masa mendatang.

3. Proporsi alokasi anggaran untuk belanja publik dalam APBD perlu lebih ditingkatkan dan diupayakan agar jumlahnya signifikan dengan pos-pos belanja daerah lainnya, dalam upaya meningkatkan akuntabilitas dan pelayanan publik secara maksimal sehingga kesejahteraan masyarakat dapat ditingkatkan lagi.

4. Diharapkan agar para peneliti selanjutnya yang tertarik untuk melakukan penelitian terhadap kinerja keuangan maupun tingkat kesejahteraan masyarakat Kabupaten Majalengka, hendaknya juga melakukan perbandingan untuk keseluruhan kabupaten/kota di Provinsi Jawa Barat, sehingga dapat diketahui lebih jelas mengenai gambaran kinerja keuangan dan tingkat kesejahteraan masyarakat Kabupaten Majalengka.

\section{Daftar Pustaka}

Badan Perencanaan dan Pembangunan Pemerintah Daerah, 2015, Rencana Pembangunan Jangka Panjang Daerah Kabupaten Majalengka Tahun 2005 2025, Kabupaten Majalengka.

Badan Perencanaan Pembangunan Nasional, 2013, Data dan Informasi Kinerja Pembangunan 2004 - 2012, Republik Indonesia, Jakarta.

Batafor, Gehi, Gregorius, 2011, Evaluasi Kinerja Keuangan Dan Tingkat Kesejahteraan Masyarakat Kabupaten Lembata - Provinsi NTT, Program Pascasarjana, Universitas Udaya, Denpasar.

Fungsi dan Tujuan Manajemen Keuangan, 2014 (http://gedeiwan.files.wordpress.com, diakses 5 Mei 2014)

Halim, Abdul. 2007. Akuntansi Sektor Publik: Akuntansi Keuangan Daerah. Salemba Empat. Jakarta.

Hamzah, Ardi, 2007. Analisa Kinerja Keuangan Terhadap Pertumbuhan Konomi,Pengangguran Dan Kemiskinan : Pendekatan Analisis Jalur (Studi Pada 29 Kabupaten Dan 9 Kota Di Provinsi Jawa Timur). Simposium Nasional Akuntansi $X$.

Handayani, Sri, 2012, Pengaruh Rasio Keuangan Daerah Terhadap Belanja Modal Untuk Pelayanan Publik Dalam Perspektif Teori Keagenan, 
Ihyig, Wulan dan Bastian, Indra. 2005. Rancangan Sistem Kesejahteraan Sosial (Social SecuritySystem) Di Indonesia Dalam Perspektif Akuntansi (Studi Empiris Propinsi Daerah Istimewa Yogyakarta). Yogyakarta.

Keputusan Menteri Dalam Negeri No.29/2002 tentang Pedoman Pengurusan, Pertanggungjawaban dan Pengawasan Keuangan Daerah serta Tata Cara Penyusunan APBD, Pelaksana Tata Usaha Keuangan Daerah dan Penyusunan Perhitungan APBD.

Matheus A.B.H. Dacosta 2002, Kemandirian Kota Kupang Ditinjau dari AspekPeraturan Menteri Dalam Negeri Nomor 29, Tahun 2002

Nardi Sunardi (2017) Determinan Kebijakan Utang Serta Implikasinya terhadap Kinerja Perusahaan (Perusahaan yang tergabung dalam indeks LQ.45 yang terdaftar di Bursa Efek Indonesia Tahun 2011- 2015) Jurnal Sekuritas, Vol. 1, No.1 / September 2017 Universitas Pamulang.

Nardi Sunardi, Aceng Abdul Hamid, Lativa, Abdul Kadim, Natanael Tulus (2018) Determinant Of Cost Efficiency And It's Implications For Companies Performance Incorporated In The Lq.45 Index Listing In Idx For The Period of 2011-2016, International Journal of Applied Business and Economic Research,.Volume 16, Number 1, 2018, ISSN : 0972-7302

Pengertian Manajemen, 2014, (http://ipdcpoa.files.wordpress.com, diakses 5 Mei 2014)

Peraturan Menteri Dalam Negeri (Permendagri) nomor 13 tahun 2006 tentang Pedoman Pengelolaan Keuangan Daerah

Peraturan Menteri Dalam Negeri Nomor 13, Tahun 2006 tentang Pedoman Pengelolaan Keuangan Daerah. 2006. Depdagri RI.

Peraturan Pemerintah Nomor 105, Tahun 2000 Peraturan Pemerintah Nomor 41, Tahun 2006 tentang Pedoman Pengelolaan Keuangan Daerah, 2006. Depdagri RI.

Peraturan Pemerintah Republik Indonesia Nomor 58 Tahun 2005 tentang Pengelolaan Keuangan Daerah.

Pertiwi, Retno dan Iriawan, Nur. 2012. Pemodelan Pengeluaran Perkapita Perkabupaten/Kota Di Kalimantan Barat Menggunakan Hirarki Bayesian. IndoMS Jurnal On Statistics Vol. xx, No.xx. 2012

Portal Gabungan Perusahaan Konstruksi Nasional Indonesia Kabupaten Majalengka, 2015, Indikator Makro Kabupaten Majalengka,

Portal Resmi Badan Pemerintah Daerah Kabupaten Majalengka, 2015, Indikator Ekonomi Kabupaten Majalengka, (http://bappeda.majalengkakab.go.id, diakses 20 Maret 2015)

Portal Resmi Badan Pusat Statistik Indonesia, 2015, Indeks Pembangunan Manusia, (http://www.bps.go.id, diakses 25 Maret 2015)

Portal Resmi Badan Pusat Statistik Jawa Barat, 2015, Indeks Pembangunan Manusia, (http://www.jabar.bps.go.id, diakses 25 Maret 2015)

Portal Resmi Badan Pusat Statistik Kabupaten Majalengka, 2015, Indeks Pembangunan Manusia, (http://www.majalengkakab.bps.go.id, diakses 25 Maret 2015)

Portal Resmi Direktorat Jenderal Perimbangan Keuangan Kementerian Keuangan, 2015, Data Keuangan Daerah, 
Portal Resmi Pemerintah Kabupaten Majalengka, 2015, Rancangan Kerangka Ekonomi Daerah Beserta Kerangka Pendanaan.

Setiyawati, Anis dan Hamzah, Ardi. 2007. Analisa PAD, DAU, DAK, dan Belanja Pembangunan Terhadap Pertumbuhan Ekonomi, Kemiskinan, dan Pengangguran. The 1st Accounting Conference. Jakarta.

Sholikhah, Ratna, 2011, Analisis Kemampuan Kemandirian Keuangan Daerah Dan Pengaruhnya Terhadap Pertumbuhan Ekonomi Kabupaten Wonogiri Tahun Anggaran 2000 - 2009, Fakultas Ekonomi Universitas Sebelas Maret, Surakarta.

Suharjo, Bambang, 2008. Analisis Regresi Terapan dengan SPSS. Penerbit Grahallmu. Yogyakarta.

Surat Edaran Menteri Dalam Negeri Nomor S.900/316/BAKD tentang Pedoman, Sistem dan Prosedur Penatausahaan dan Akuntansi Pelaporan dan Pertanggungjawaban Keuangan Daerah. 2006. Depdagri RI.

Swandewi, Agung, Istri, Agung, Anak. 2014. Pengaruh Dana Perimbangan Dan Kemandirian Keuangan Daerah Terhadap Keserasian Anggaran Dan Kesejahteraan Masyarakat Pada Kabupaten/Kota Di Provinsi Bali. Fakultas Ekonomi dan Bisnis Universitas Udayana (Unud), Bali.

Thesaurianto, Kuncoro. 2007. Analisis pengelolaan keuangan Daerah terhadap kemandirian Daerah. Program Studi Magister IImu Ekonomi Dan Studi Pembangunan, Universitas Diponegoro, Semarang.

Undang-undang Nomor 32, Tahun 2004 tentang Pemerintahan Daerah, 2004. Depdagri RI.

Undang-undang Nomor 33, Tahun 2004 tentang Perimbangan Keuangan Pemerintah Pusat dan Daerah, 2004. Depdagri RI.

Yustika, Abdul S, 2004, Otonomi dan Pembangunan Daerah. Erlangga. Jakarta 